\title{
Susceptibility of Four Tropical Lepidopteran Maize Pests to Bacillus thuringiensis CryI-Type Insecticidal Toxins
}

\author{
N. BOHOROVA, ${ }^{1}$ M. CABRERA,${ }^{2}$ C. ABARCA,${ }^{2}$ R. QUINTERO,${ }^{2}$ A. M. MACIEL, ${ }^{1}$ \\ R. M. BRITO, ${ }^{1}$ D. HOISINGTON, ${ }^{1}$ AND A. BRAVO ${ }^{2}$
}

\begin{abstract}
J. Econ. Entomol. 90(2): 412-415 (1997)
ABSTRACT The relative susceptibility of 4 tropical maize pests, Spodoptera frugiperda (J. E. Smith), Diatraea grandiosella Dyar, D. saccharalis (F.), and Helicoverpa zea (Boddie), to the lepidopteran-specific CryI-type proteins produced by B. thuringiensis is presented. The toxin with the highest potency against $H$. zea larvae was the CryIAc toxin. S. frugiperda larvae were susceptible to CryID and CryIF toxins. The CryIB toxin showed to be highly toxic against $D$. grandiosella and $D$. saccharalis. This information will establish a basis for selecting $B$. thuringiensis strains producing the appropriate $\mathrm{CryI}$ proteins to be used for the biological control of these tropical pests.
\end{abstract}

KEY WORDS Spodoptera frugiperda, Diatraea grandiosella, Diatraea saccharalis, Helicoverpa zea, Bacillus thuringiensis, $\delta$-endotoxin

Bacillus thuringiensis (BERLINER) is a gram-positive bacterium that produces crystallic protein inclusions during sporulation. This inclusions are formed by proteins called $\delta$-endotoxins or insecticidal crystal proteins (ICP), which are toxic to insect larvae, many of which are disease vectors or major crop pests. The use of $B$. thuringiensis as a microbial insecticide has several advantages over the use of chemical control agents; $B$. thuringiensis strains are highly specific for certain hosts and are not toxic to other insects, and plants and vertebrates and are completely biodegradable so no residual toxic products accumulate in the environment. Preparations of $B$. thuringiensis-based insecticides applied to the foliage are washed off by rain and may be inactivated by sunlight; therefore, only relatively short-term protection from pest populations is obtained from single applications.

It has been estimated that up to $15 \%$ of crops worldwide are lost because of insect damage alone (Boulter et al. 1989). Insecticidal crystal proteins from $B$. thuringiensis have been used as biopesticides during the past $30 \mathrm{yr}$ and a wide array of commercial products are now available and used in the field. Furthermore, some ICP genes have been introduced into the plant genome, with a high level of protection from insect attack (Vaeck et al. 1987, Perlak et al. 1990).

Bacillus thuringiensis strains can be isolated from soil samples from all over the world on plant surfaces, dead insects, and stored grains. Currently,

\footnotetext{
International Maize and Wheat Improvement Center, CIMMYT, Ap. Postal 6-64l, 06600 México, D.F., México.

${ }^{2}$ Instituto de Biotecnología-UNAM, Ap. Postal 510-3, Cuemavaca 62250, Morelos, México.
}

45 different serotypes and 8 nonflagellated biotypes have been cataloged (Lecadet et al. 1994). Numerous ICP genes have been cloned, sequenced, and classified, based on their homology and specificity (Höfte and Whiteley 1989). To date, 11 subgroups of cryI genes specific to lepidopteran pests have been characterized and identified. Each CryI toxin has a narrow range of toxicity against different lepidopteran insects (Feitelson et al. 1992). Five cryIII genes specific against coleopteran pests have been described. Both insect orders contain some of the most devastating agricultural pests.

The search for novel $B$. thuringiensis ICPs is a priority worldwide. This toxin will provide different altematives for insect control and for coping with the problem of insect resistance. In this sense, it is important to have a methodology that allows for accurate identification of the most active toxins against selected pests. The analysis of toxic activity through bioassay allows the identification of the powerful toxins against a particular insect.

Maize (Zea mays L.) is one of the principal crops in Mexico and other developing countries, where it is used for human and animal nutrition. The crop is a target of many different pests including 4 lepidoptera species: $S$. frugiperda, $D$. grandiosella, $D$. saccharalis, and $H$. zea. The objective of the current study was to determine the relative susceptibility of these 4 tropical pests to the lepidopteran specific proteins produced by $B$. thuringiensis.

\section{Materials and Methods}

Purification of Insecticidal Crystal Proteins. Insecticidal crystals containing CryIAa, CryIAb, 
and CryIAc protoxins were purified from $B$. thuringiensis $\mathrm{HD} 1$ strain. CryIAc protoxin was purified from B. thuringiensis subsp. kurstaki HD73 strain. CryIE toxin was purified from $B$. thuringiensis HD125 strain and CryIF from $B$. thuringiensis 1B181 strain. CryIAb, CryIC, and CryID protoxins were obtained as recombinant proteins expressed in Escherichia coli. The cryIAb gene was cloned from $B$ thuringiensis subsp. berliner 1715 (Höfte et al. 1986). The cryID gene was cloned from $B$. thuringiensis subsp. aizawai HD68 (Höfte et al. 1990). The cryIC gene was cloned from $B$. thuringiensis subsp. entomocidus 60.5 (Honée et al. 1988). E. coli transformant strains were kindly supplied by M. Peferoen (Plant Genetic Systems, Gent, Belgium). CryIB protoxin was purified from the Mexican isolated $B$. thuringiensis subsp. thuringiensis IB43 strain. This strain was characterized by enzyme-linked immunosorbent assay (ELISA) using a specific monoclonal antibody against CryIB toxin and polymerase chain reaction (PCR) analysis using specific primers for the cryIB gene described in Cerón et al. (1994).

Crystalline inclusions produced in $B$. thuringiensis strains were purified from spores and cell debris by centrifugation in discontinuous sucrose gradients as described by Thomas and Ellar (1983). Cells were grown in nutritive medium (Difco, Detroit MI) until complete sporulation was achieved. Spores and crystals were centrifuged at $6,000 \times g$ for $10 \mathrm{~min}$ at $4^{\circ} \mathrm{C}$. The pellet was washed 4 times with deionized water. The final pellet was resuspended in $50 \mathrm{mM}$ Tris $\mathrm{HCl}(\mathrm{pH}$ 7.5). Spores and crystals were layered on top of a 30 -ml discontinuous sucrose gradient, composed of $6 \mathrm{ml}$ each of $67,72,79,84$, and $90 \%$ (wt:vol) sucrose in $50 \mathrm{mM}$ Tris $\mathrm{HCl}$, ( $\mathrm{pH}$ 7.5). Centrifugation was carried out at $80,000 \times g$ for $14 \mathrm{~h}$ at $4^{\circ} \mathrm{C}$. Crystals formed a major band at the interface between 72 and $79 \%$ sucrose or between 79 and $84 \%$ sucrose, while the spores formed a discrete pellet at the bottom of the tube. The crystal band was removed and washed 3 times in $50 \mathrm{mM}$ Tris $\mathrm{HCl}(\mathrm{pH} \mathrm{7.5)}$ and centrifuged at $15,000 \times \mathrm{g}$ for $5 \mathrm{~min}$ at $4^{\circ} \mathrm{C}$ to remove the sucrose. The final pellet was resuspended in deionized water. Purity of the crystal preparation was monitored by phase contrast microscopy. If necessary, a 2nd centrifugation in the discontinuous sucrose gradients was performed. Crystal inclusion bodies were solubilized in $0.1 \mathrm{M} \mathrm{NaHCO}_{3}, 10 \mathrm{mM} \beta$-mercaptoethanol, $\mathrm{pH}$ 9.5 for $4 \mathrm{~h}$ at $37^{\circ} \mathrm{C}$. After centrifugation at 15,000 $\times g$ for $10 \mathrm{~min}$, protein concentrations were determined by using the Bradford procedure (Bradford 1976) with bovine serum albumin as a protein standard and sodium dodecyl sulphate/polyacrylamide gel electrophoresis (SDS-PAGE) was conducted as described by Laemmli (1970)

The insecticidal proteins produced in the recombinant $E$. coli strains were purified from 500 $\mathrm{ml}$ of saturated culture in LB medium (Sambrook et al. 1989) supplemented with the corresponding antibiotic. Cells were suspended in $50 \mathrm{mM}$ Tris $\mathrm{HCl}$ ( $\mathrm{ph} 7.5$ ), $50 \mathrm{mM}$ EDTA, 15\% sucrose, treated with lysozime $(100 \mathrm{mg} / \mathrm{ml})$ for $30 \mathrm{~min}$ at $37^{\circ} \mathrm{C}$ and sonicated on ice 4 times for $1 \mathrm{~min}$. The cell debris was washed twice with $200 \mathrm{ml}$ of 50 $\mathrm{mM}$ Tris $\mathrm{HCl}, 150 \mathrm{mM} \mathrm{NaCl}$ (ph 7.5), containing $2 \%$ triton X-100, incubated for $30 \mathrm{~min}$ in the same buffer at $0^{\circ} \mathrm{C}$, centrifuged at $15,000 \times g$ for 10 min, and washed twice with $50 \mathrm{mM}$ Tris $\mathrm{HCl}, 150$ $\mathrm{mM} \mathrm{NaCl}$, (ph 7.5). B. thuringiensis protoxins present in the pellet were solubilized in $0.1 \mathrm{M}$ $\mathrm{NaHCO}_{3}, 10 \mathrm{mM} \beta$-mercaptoethanol pH 9.5 for 4 $\mathrm{h}$ at $37^{\circ} \mathrm{C}$ and centrifuged at $15,000 \times \mathrm{g}$ for 10 min. Solubilized protein was loaded on a Sephacryl S-300 column $(100 \times 2.5 \mathrm{~cm})$ and eluted with a flow rate of $40 \mathrm{ml} / \mathrm{h}$.

Toxicity Assays. Larvae of $S$. frugiperda, $D$. grandiosella, D. saccharalis, and $H$. zea were obtained from colonies established in the Entomological Rearing Facility at CIMMYT (Mexico) where the bioassay were done.

Artificial diets, prepared as described by Mihm $(1982,1983 a, b)$ were used for all tests. Each toxin was diluted in water, mixed with a vortex mixer for $1 \mathrm{~min}$, sonicated, and added to the diet at the rate of 10 or $100 \mathrm{mg} / \mathrm{g}$ diet. The mixture was poured into each well of a 32-well microtiter plates (Cell Wells, Corning Glass Works, Coming, New York). The diet was allowed to solidify and a single larvae (I-d-old larvae of S. frugiperda, D. grandiosella, and $D$. saccharalis and 2-d-old larvae of $H$. zea) was added to each well. Microtiter plates were covered with polyester film lidding material and incubated in a growth chamber at $27^{\circ} \mathrm{C}, 65 \pm 5 \%$ $\mathrm{RH}$, and a photoperiod of 16:8 (L:D) h. Thirty-two insects were evaluated per toxin and each treatment was replicated at least 3 times. Mortality was assessed after $7 \mathrm{~d}$.

Mortality of the control larvae reared on a toxinfree diet and under the same conditions was recorded and used to correct the mortality test with Abbott formula (Abbott 1925) The $\mathrm{LC}_{50}$ values and confidence limits were obtained by probit analysis (Finney 1971).

\section{Results and Discussion}

Bioassays with neonate lepidopteran larvae were performed with the CryI type ICPs. It has been reported that these proteins are highly specific against lepidoteran insects. The percentage of mortality obtained with $10 \mathrm{mg}$ of each toxin applied per gram of artificial diet is presented in Fig. I.

Helicoverpa zea is a serious pest of highland maize crops. We found that the toxin with the highest potency against $H$. zea larvae was the CryIAc toxin (Fig. 1; Table 1). This insect was also susceptible to the CryIAb toxin (Fig. 1). These data are in agreement with previous bioassays that showed that CryIAc has a LC $_{50}$ values of 464 $\mathrm{ng} / \mathrm{cm}^{2}$ on $H$. zea larvae (Garczynski et al. 1991). However, there is noinformation regarding the sus- 

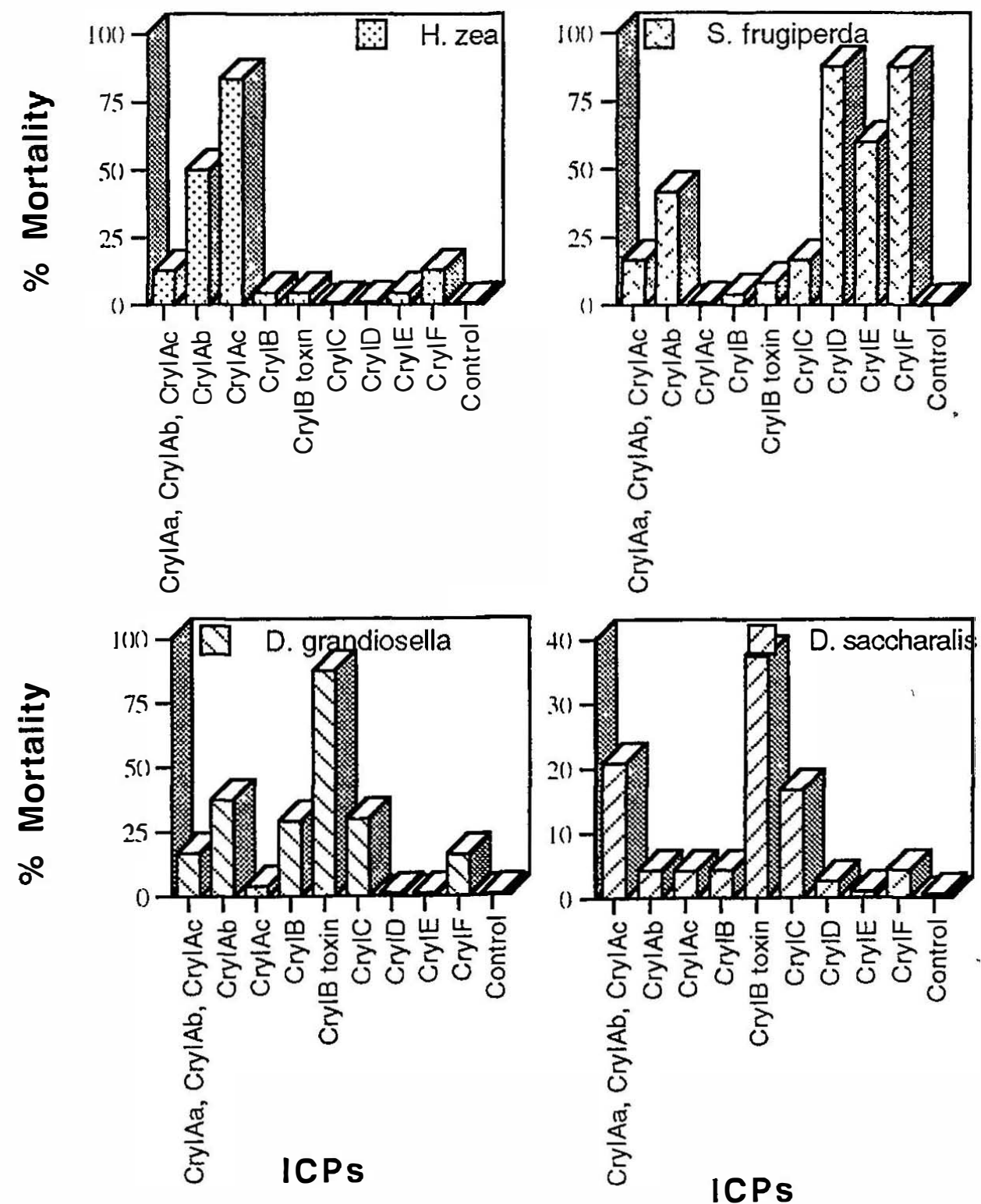

Fig. 1. Response of 4 different lepidopteran insects to CryI insecticidal crystal proteins from B. thuringiensis. Percentage mortality obtained with $10 \mathrm{mg}$ of each toxin appled per gram of artificial diet.

ceptibility of this insect toward other Cry toxins. Other Heliothis species are also highly susceptible to CryIAc. For example, $H$. virescens, which is a cotton crop pest that was shown to be highly susceptible to CryIAc and CryIAb toxins, presented $L_{50}$ of 2 and $7 \mathrm{ng}$, respectively, of toxin applied over the surface of $1 \mathrm{~cm}^{2}$ of artificial diet (Van Rie et al. 1989).

Table I. Toxicity of Cry toxins on lepidopteran insects

\begin{tabular}{lcccc}
\hline \hline \multicolumn{1}{c}{ Insect } & ICP & LC $_{50}$ & CI I5 & $n$ \\
\hline D. grandiosella & CryIB & 5.2 & $3.6-55$ & 7 \\
D saccharalss & CryIB & 113.6 & $45.8-318.9$ & 3 \\
S. frugiperda & CryID & 1.54 & 0.4 & 4 \\
H zea & CryIAc & 8.2 & 7. & 3 \\
\hline
\end{tabular}

Data are expressed in micrograms of toxan applied per gram of artificial diet. $95 \% \mathrm{CI}$ were calculated from probit analysis. $n$, Number of replications.
Information regarding the susceptibility of $S$. frugiperda to the Cry protein family is limited. The larval stage of this insect is an important pest of maize, cotton, alfalfa, clover, peanuts, and many garden crops. The CryIC toxin has been reported to be toxic against S. exigua (Visser et al. 1990) and S. littoralis (Van Rie et al. 1990 ) with $\mathrm{LC}_{50}$ values of 68 and $93 \mathrm{ng} / \mathrm{cm}^{2}$, respectively. CryID and CryIE have been reported to be toxic to $S$. littoralis with $\mathrm{LC}_{50}$ of 423 and $88 \mathrm{ng} / \mathrm{cm}^{2}$, respectively (Van Rie et al. 1990). In this study, we analyzed the susceptibility of $S$. frugiperda larvae to the family of CryI toxins and we found that the toxins with the highest activity were CryID and CryIF toxins (Fig. 1).

There is little information regarding the control of $D$. grandiosella or $D$. saccharalis by $B$. thuringiensis ICPs. We found that both types of larvae are highly susceptible to CryIB toxin (Fig. 1). Table 1 shows the $\mathrm{LC}_{50}$ and the confidence intervals 
for the $D$ grandiosella and $D$ saccharalıs bioassays. The CryIB protein was highly toxac to $D$ grandiosella, $\mathrm{LC}_{50}$ of $51 \mathrm{mg} / \mathrm{g}$ artuficial diet was obtained CrylB toxn was found to be $\approx 20$ tmes less active against $D$ saccharalis

Our findings indicate that no single ICP is active against all pests species However, these results will be important in selecting $B$ thuringiensis strains producing the appropnate CryI protein to be used for the biological control of each of these tropical pests or the different ICPs combinations needed to control mazze pests, where muxed insect populations attack the crop Also, the knowledge of which toxin has the higher activity against a selected pest will set the basis for selectng which genes will be most appropnate in transgenic plants generation

\section{Acknowledgments}

We thank $M$ Peferoen for providing recombinant $E$ colı strains and Mynam Ortíz for stram maintenance This work was supported in part by UNDP, DGAPA IN-214294 and CONACyT 400344-5-4311N

\section{References Cited}

Abbott, W. S. 1925. A method of computing the effectiveness of an insecticide J Econ Entomol 18 265-267

Boulter, D., A.M.R. Gatehouse, and V. Hilder. 1989. Use of cowpea trypsin inhibitor (CPTI) to protect plants against insect predation Biotech Adv 7 489497

Bradford, M. M. 1976. A rapid and sensituve method for the quantitation of microgram quantites of protein utlizing the pnnciple of protem-dye binding Anal Brochem 72 248-254

Cerón, J., L. Covarrubias, R. Quintero, A. Ortiz, M. Ortiz, E. Aranda, L. Lina, and A. Bravo. 1994. PCR analysis of the cryI insecticidal crystal family genes from Bacillus thurngiensis Appl Envron M1crobiol 60 353-356

Feitelson, J. S., J. Payne, and L. Kim. 1992. Bactllus thuringiensis insects and beyond Brotechnology 10 271-275

Finney, D. J. 1971. Probit analysis Cambndge Unıversity Press, Cambndge

Garczynski, S. F., J. W. Crim, and M. J. Adang. 1991. Identfication of putative insect brush border membrane-binding molecules specific to Bacillus thurngiensis d-endotoxan by protein blot analysis Appl Environ Microbiol 57 2816-2820

Höfte, H., H. Greve, J. Seurink, S. Jansens, J. Mabillon, C. Ampe, J. Van dekerckhove, H. Van derbruggen, M. Van Montagu, M. Zabeau, and $M$. Vaeck. 1986. Structural and functional analysis of a cloned delta-endotoxn of Bacillus thurngiensis berliner 1715 Eur J Biochem 161 272-280

Hofte, H., P. Soetaert, S. Jansens, and M. Peferoen. 1990. Nucleotide sequence and deduced amino acid sequence of a new Lepidopteran-specific crystal protein gene from Bacillus thurngiensis Nuclerc Acrds Res 185545

Höfte, H., and H. R. Whiteley. 1989. Insecticidal crystal proteins of Bacillus thurngiensis Microbiol Rev 53 242-255

Honée, G., T. van der Salm, and B. Visser. 1988. Nucleotade sequence of crystal protem gene isolated from $B$ thuringiensis subspecies entomocidus 605 coding for a toxan highly active aganst Spodoptera species Nuclerc Acids Res 166240

Laemunli, U. K. 1970. Cleavage of structural protems dunng the assembly of the head of bactenophage T4 Nature (Lond) 227 680-685

Lecadet, M. M., E. Frachon, V. Cusmao-Dumanoir, and H. De Barjac. 1994. An update version of the Bacillus thurnngensis strains classificaton according to H-serotypes, pp 345 Second International Conference on Bacillus thurnngensis, Montpelher France, 28 August-2 September Société Viganarse d'Impnmene, Ganges, France

Mihm, J. 1982. Techniques for efficient mass reanng and infestation in screening for host plant resistance to corn earworm Heliothis zea CIMMYT, Mexaco

1983a. Techniques for efficient mass reanng and infestation of fall armyworm, Spodoptera frugiperda (J E Smith), for host plant resistance studies CIMMYT, Mexaco

1983b. Technıques for efficient mass reanng and infestation in screening for host plant resistance to Diatraea sp maze stem borers CIMMYT, Mexco

Perlak, F. J., R. W. Deaton, T. A. Armstrong, R. L. Fuchs, S. R. Sims, J. T. Greeanplate, and D. A. Fihshoff. 1990. Insect resistant cotton plants Bio technology 8 939-943

Sambrook, J., E. F. Fritsch, and T. Maniatis. 1989. Molecular cloning A laboratory manual 3 Cold Spnng Harbor Laboratory Press, Cold Spnng Harbor, $\mathrm{NY}$

Thomas, W. E., and D. J. Ellar. 1983. Bacillus thuringiensis var israelensis crystal d endotoxan effect in insect and mammalian cells in vitro J Cell $\mathrm{Scl} 60$ 181-197

Vaeck, M., A. Reynaerts, H. Höfte, S. Jansens, M. De Beuckeller, C. Dean, M. Zabeau, M. Van Montagu, and J. Leemans. 1987. Transgenic plants protected from insect attack Nature (Lond) 328 33-37

Van Rie, J., S. Jansens, H. Höfte, D. Degheele, and H. Van Mellaert. 1989. Specificity of Bacillus thurngiensis delta-endotoxans importance of specific receptors on the brush border membrane of the midgut of target insects Eur J Biochem 186 239-247

Van Rie, J., S. Jansens, H. Hofte, D. Degheele, and H. Van Mellaert. 1990. Receptors on the brush border membrane of the insect midgut as determ1nants of the specificity of Bacillus thurnngensis deltaendotoxans Appl Environ Microbiol 56 1378-1385

Visser, B., E. Munsterman, A. Strokes, and W. G. Dirlese. 1990 A novel Bacillus thurngiensis gene encoding a Spodoptera exigua specific crystal protem J Bactenol 172 6783-6788

Received for publication 1 March 1996, accepted 9 December 1996 